\title{
Analysis of the Impact of the Construction of a Gate on the Macroscopic Structure of a Casting and Its Influence on the Mechanical Properties of Castings
}

\author{
Ján Majerník, Ján Kmec, Monika Karková \\ Institute of Technology and Business in České Budějovice, Okružní 517/10, 370014 České Budějovice, Czech Republic, \\ E-mail: majernik@mail.vstecb.cz
}

\begin{abstract}
The macroscopic structure of a casting has a direct impact on its mechanical properties. The porosity and homogeneity of a casting closely correlate with its tear strength characteristics. In order to achieve the best mechanical properties, it is necessary to eliminate internal defects in a casting. The elimination of such defects can be achieved through the suitable adjustment of the input parameters of high pressure die casting machines prior to starting the actual casting cycle. This method is useful for companies that produce castings on the basis of supplied pressure forms, whereby it is impossible to influence the design of the gating systems. A much more appropriate way to influence the homogeneity of a casting is to design the gating system so that possible shortcomings are already underpinned and excluded in the design and development phases. By adjusting various elements of the gating systems it is possible to achieve significant improvements in the properties of a casting. The construction of the gate has the biggest influence on the final homogeneity of a casting. The gate is the point at which the modulation of the melt flow rate takes place for the filling of the die cavity. The mode in which the cavity is filled and the speed of the melt flow rate are the main determinants of the final characteristics and properties of a casting. This paper presents an analysis of the macroscopic structures of castings produced under various gate construction modifications and their effect on the mechanical properties of those castings. Conclusions, which are drawn on the basis of the detailed analysis, describe the correlation between the macroscopic structures and the mechanical properties of castings with precautionary measures that are used and implemented directly in production.
\end{abstract}

Keywords: macroscopic structure, mechanical properties, construction

\section{References}

[1] Norma STN 420491, Zliatiny AlSi na odliatky, Hodnotenie metalografickej štruktúry

[2] MELNIKOV, A. V., LEBEDEV, V. M. (1974). Vysokopročnyje $i$ žaropročnyje litejnyje aluminijevyje splavy, Moskva, 1974

[3] MICHNA, Š. et al. (2005). Encyklopedie hliniku. 1. vyd. Dêčín: ALCAN, 2005, s. 699, ISBN 8089041884

[4] Norma STN EN 6506-1 (STN 420371), Kovové materiály, Brinellova skúška tvrdosti, Čast' 1: Skúšobná metóda

[5] ROUČKA, J. (2004). Metalurgie neželezných slitin. 1. vyd. Brno: Akademické nakladatelství CERM, 2004, s. 148, ISBN 8021427906

[6] PETI, F., GRAMA, L., SOLOVASTRU, L., CORB, C. (2010). Studies concerning the design of the runner, gate and venting systems in the case of the high pressure die casting technology. In: Fascicle of Management and Technological Engineering. Vol. 29, No. 9/2010, p. 3177-3183, ISSN 1583-0691

[7] STUNOVÁ, B.; NOVOTNÝ, F.; PROKOP, J. (2010). Computer Tomography in Comparison with Other Testing Methods Used for the Leakage Testing of HPDC Parts. MANUFACTURING TECHNOLOGY 2010, 10, 29-34. ISSN 1213-2489

[8] GREGER, M., WIDOMSKÁ, M. (2011). Analysis of influence of structure on mechanical properties of AlSiMg aluminium alloy processed by ECAP. MANUFACTURING TECHNOLOGY, 2011, vol. 11, p. 17-22. ISSN 12132489

[9] LIPIŃSKI, T. (2011). Use Properties of the AlSi9Mg Alloy With Exothermical Modifier. MANUFACTURING TECHNOLOGY, 2011, vol. 11, p. 44-49. ISSN 1213-2489

[10] LIPIŃSKI, T. (2011). Microstructure and Mechanical Properties of the AlSi13Mg1CuNi Alloy With Ecological Modifier. MANUFACTURING TECHNOLOGY, 2011, vol. 11, p. 40-44. ISSN 1213-2489

[11] Norma STN 420491, Zliatiny AlSi na odliatky, Hodnotenie metalografickej štruktúry

[12] PAŠKO, J. (2010). Die Casting Plunger Pressing Velocity and Analysis of Its Influence on a Permanent Deformation Value of a Casting Made from an ENAC 47100 Alloy. MANUFACTURING TECHNOLOGY, 2010, vol. 10, p. 23-26. ISSN 1213-2489

[13] PAŠKO, J., GAŠPÁR, S̆. (2013). Experimental monitoring of HB hardness and ultimate tensile strenght UTS of pressure of Al-Si castings depending on the increase pressure changes. In: Advanced Materials Research, Vol. 711, 2013, p. 272-275, ISSN 1022-6680 